Check for updates

Cite this: RSC Adv., 2017, 7, 52266

\title{
Antimicrobial effect of gallium nitrate against bacteria encountered in burn wound infections
}

\author{
Zhaorong $\mathrm{Xu}^{\mathrm{a}}{ }^{\mathrm{X}}$ Xiaolong Zhao, ${ }^{\mathrm{b}}$ Xiaodong Chen, ${ }^{\mathrm{a}}$ Zhaohong Chen ${ }^{\mathrm{a}}$ \\ and Zhaofan Xia (D)*ac
}

Recently, biomaterials have been increasingly used for burn wound healing, but burn wound infections and biomaterial-associated infections still need to be addressed. As a novel inorganic antimicrobial, the antimicrobial effect of gallium nitrate was investigated, and the minimum inhibitory concentration (MIC) of gallium nitrate against bacteria that are common in infected burn wounds was determined with a Microbial Viability Assay Kit-WST. The results showed that the MIC of $\mathrm{Ga}\left(\mathrm{NO}_{3}\right)_{3}$ against $E$. coli and $E$.

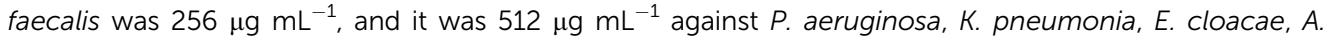
baumannii, S. maltophilia, S. aureus and S. epidermidis. Meanwhile, transmission electron microscopy (TEM) found similar visual evidence of the mechanism by which the gallium ion attacks both Gramnegative and Gram-positive bacteria, which was in agreement with the MIC results. By TEM observation, it was found that detachment of the cell membrane and wall and the appearance of an electron-light region containing condensed substances occurred in both $\mathrm{Ga}^{3+}$-treated $E$. coli and $\mathrm{Ga}^{3+}$-treated $S$. aureus cells, with smaller morphological changes in $\mathrm{Ga}^{3+}$-treated S. aureus compared with E. coli. This research shows the effective and wide-spectrum antimicrobial properties of gallium nitrate against most bacteria encountered in burn wound infections. Gallium(III) could be a good choice when fighting an infected burn wound, and it is a promising candidate for modifying biomaterials or medical devices to

Received 15th September 2017 Accepted 1st November 2017

DOI: 10.1039/c7ra10265h prevent infection in burn wounds.

rsc.li/rsc-advances

\section{Introduction}

In recent years, due to the development of molecular biology and tissue engineering technology, biomaterials, including engineered skin tissue, have been rapidly developed, making it possible for severe burn patients without enough skin for grafting to still be cured and to have physiological functions reestablished. ${ }^{1}$ However, it cannot be ignored that biomaterialassociated infections frequently occur with implants and devices, especially those for supporting or restoring normal skin functions. ${ }^{2,3}$ Nevertheless, comparatively few biomaterials have been prepared to efficiently decrease the incidence of biomaterial-associated infections.

At the same time, for burn patients, the wound bed is an ideal medium for the survival and spread of bacteria because it contains rich nutrients due to the leakage of inflammatory mediators and the dissolving of necrotic tissue. What is more serious is that pathogens can easily invade adjacent healthy tissues and spread to the bloodstream in patients with severe

\footnotetext{
${ }^{a}$ Fujian Burn Institute, Fujian Medical University Union Hospital, Fuzhou 350001, Fujian, China. E-mail: xiazhaofan@163.com

${ }^{b}$ Department of Orthopaedics, Luohe Central Hospital, Luohe 462000, Henan, China 'Department of Burn Surgery, Changhai Hospital, Second Military Medical University, Shanghai 200433, China
}

burns who have lost normal immune function, leading to a lifethreatening infection, sepsis. ${ }^{4}$ The treatment of wound infection in burn patients has always been one of the most intractable problems, since heavy antibiotic use has greatly increased antibiotic resistance. ${ }^{5}$ Therefore, ideal agents against biomaterial-associated infection and burn wound infection that are effective, can operate against a wide spectrum of pathogens, and are safe are greatly needed, including inorganic antimicrobials.

Inorganic antimicrobials, which provide an environment with a relatively high concentration of metal ions, can change the membrane potential and induce a difference in ion concentrations, thus destroying the molecules' transportation. Meanwhile, the heavy metal ions can inactivate important enzymes by destroying the conformation of the enzyme or damaging/displacing metal ions, which are necessary to sustain the enzymatic activity, resulting in energy metabolism disorder. In addition, intracellular metal ions can combine with nucleic acids, which may interfere with the bacterial proliferation process. ${ }^{6-10}$ For these antibacterial mechanisms, inorganic antimicrobials possess the advantages of effectiveness, the ability to affect a wide spectrum of bacteria, and less vulnerability to acquired resistance.

Recently, several metallic antimicrobial agents, such as silver, copper and zinc, have been introduced and 
investigated..$^{11-13}$ These metallic antimicrobial agents also include gallium. ${ }^{14,15}$ Gallium (Ga, $69.72 \mathrm{~g} \mathrm{~mol}^{-1}$ ) is a transition metal element, which has a similar ionic radius to that of iron. Currently, the efficacy and safety of a variety of compounds containing gallium that are widely used to treat cancer and hypercalcemia, have been confirmed. ${ }^{16-20}$ The first investigation of the antimicrobial action of gallium was published in $1931 .^{21} \mathrm{It}$ has been reported that gallium $\left(\mathrm{Ga}^{3+}\right)$ exerts a significant inhibitory activity against numerous bacteria including Staphylococcus aureus, methicillin-resistant S. aureus, Rhodococcus equi, Pseudomonas aeruginosa, Acinetobacter baumannii and Escherichia coli. ${ }^{22-26} \mathrm{Ga}^{3+}$, in the form of $\mathrm{Ga}\left(\mathrm{NO}_{3}\right)_{3}$ solution (Ganite; Genta), is already FDA approved and given in large doses (i.v.) to treat hypercalcemia of malignancy. ${ }^{16} \mathrm{Ga}^{3+}$ has an ionic radius identical to $\mathrm{Fe}^{3+}$, which is vitally important in many biologic systems as it can disrupt iron-dependent oxidation and reduction. As a result, $\mathrm{Fe}^{3+}$ is prevented from combining with proteins and chelating agents, and the bacterial DNA synthesis and various oxidationreduction reactions are interfered with because of the competitive inhibition by $\mathrm{Ga}^{3+} \cdot{ }^{27}$ Due to its antimicrobial ability, $\mathrm{Ga}^{3+}$ has been proposed as a topical wound treatment. ${ }^{28}$

The objective of this research was to explore the antimicrobial effect and to determine the minimum inhibitory concentration (MIC) values of $\mathrm{Ga}\left(\mathrm{NO}_{3}\right)_{3}$ solution against bacteria that are common in burn wound infections, by using a Microbial Viability Assay Kit-WST. Meanwhile, transmission electron microscopy (TEM) was chosen with the aim of observing in detail the microscopic morphological and structural changes of bacteria interacting with gallium nitrate.

\section{Material and methods}

\subsection{Chemicals, microbial strains, culture media}

$\mathrm{Ga}\left(\mathrm{NO}_{3}\right)_{3} \cdot x \mathrm{H}_{2} \mathrm{O}$ (crystalline, $99.9 \%$ trace metals basis) was bought from Sigma-Aldrich and dissolved in water. Then, inductively coupled plasma mass spectrometry (ICP-MS) was employed to accurately identify the concentration of gallium ions, due to the uncertainty of the water content in the crystalline form.

Nine microbial strains, including Gram-positive: Staphylococcus aureus (ATCC25923), Staphylococcus epidermidis (FSCC223011), and Enterococcus faecalis (FSCC146002), and Gram-negative: Escherichia coli (ATCC25922), Pseudomonas aeruginosa (ATCC27853), Klebsiella pneumoniae (FSCC167002),

Table 1 Optimal cell density for inoculation of different bacteria in WST- 8 tests

\begin{tabular}{|c|c|c|c|}
\hline $\begin{array}{l}\text { Strains } \\
\text { (Gram-negative) }\end{array}$ & $\begin{array}{l}\text { Density } \\
\left(\mathrm{CFU} \mathrm{mL}^{-1}\right)\end{array}$ & $\begin{array}{l}\text { Strains } \\
\text { (Gram-positive) }\end{array}$ & $\begin{array}{l}\text { Density } \\
\left(\text { CFU } \mathrm{mL}^{-1}\right)\end{array}$ \\
\hline E. coli & $5 \times 10^{3}$ & S. aureus & $10^{5}$ \\
\hline P. aeruginosa & $5 \times 10^{7}$ & S. epidermidis & $10^{7}$ \\
\hline K. pneumoniae & $5 \times 10^{3}$ & E. faecalis & $10^{4}$ \\
\hline E. cloacae & $10^{4}$ & & \\
\hline A. baumannii & $5 \times 10^{3}$ & & \\
\hline S. maltophilia & $10^{7}$ & & \\
\hline
\end{tabular}

(a)

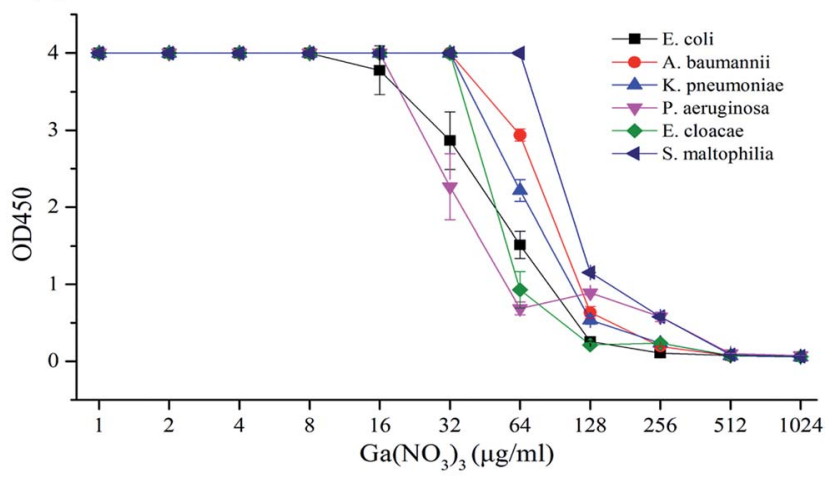

(b)

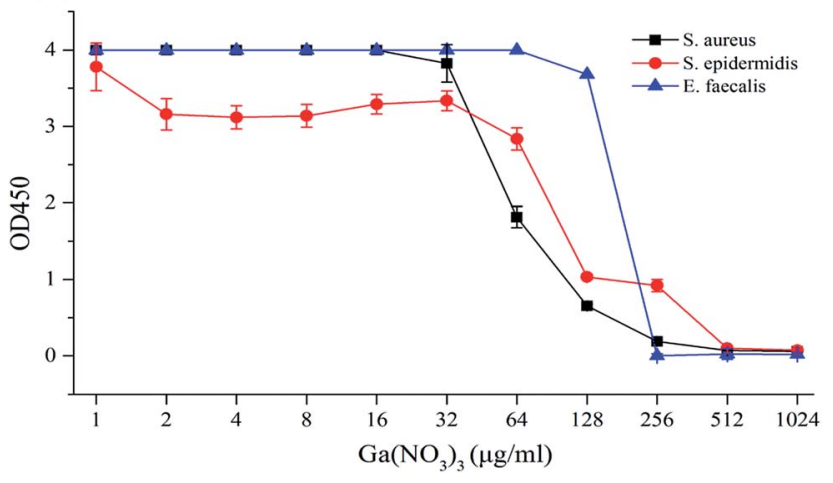

Fig. 1 Antimicrobial susceptibility curves of $\mathrm{Ga}\left(\mathrm{NO}_{3}\right)_{3}$.

Enterobacter cloacae (FSCC145003), Acinetobacter baumannii (ATCC19606), and Stenotrophomonas maltophilia (ATCC51331) were selected. Culture media were as follows: tryptic soy broth (TSB), Mueller-Hinton ( $\mathrm{MH}$ ) broth, and brain heart infusion (BHI) broth. All above were bought from GUANGDONG HUANKAI MICROBIAL SCI. \& TECH. CO., LTD.

\subsection{Inductively coupled plasma mass spectrometry (ICP-MS)}

Determination of the gallium ion concentration was performed on a NexION 300X apparatus (Perkin-Elmer, Waltham, MA). Operating conditions of $1300 \mathrm{~W}$ Rf power, $13 \mathrm{~L} \mathrm{~min}^{-1}$ plasma flow, $0.82 \mathrm{~L} \mathrm{~min}^{-1}$ nebulizer flow and peak jump mode were used. The calibration solution was made from a dilution of a standard stock solution $\left(10 \mathrm{mg} \mathrm{L}^{-1}\right)$ with $2 \%$ nitric acid. The analytical process was carried out in accordance with the order of blank, calibration solution and sample. Both ${ }^{69} \mathrm{Ga}$ and ${ }^{71} \mathrm{Ga}$

Table 2 The MIC of $\mathrm{Ga}\left(\mathrm{NO}_{3}\right)_{3}$ against bacteria strains

\begin{tabular}{|c|c|c|c|}
\hline $\begin{array}{l}\text { Strains } \\
\text { (Gram-negative) }\end{array}$ & $\begin{array}{l}\mathrm{MIC} \\
\left(\mu \mathrm{g} \mathrm{mL}^{-1}\right)\end{array}$ & $\begin{array}{l}\text { Strains } \\
\text { (Gram-positive) }\end{array}$ & $\begin{array}{l}\text { MIC } \\
\left(\mu \mathrm{g} \mathrm{mL}^{-1}\right)\end{array}$ \\
\hline E. coli & 256 & S. aureus & 512 \\
\hline P. aeruginosa & 512 & S. epidermidis & 512 \\
\hline K. pneumoniae & 512 & E. faecalis & 256 \\
\hline E. cloacae & 512 & & \\
\hline A. baumannii & 512 & & \\
\hline S. maltophilia & 512 & & \\
\hline
\end{tabular}


isotopes were used in order to control for possible interference and matrix effects. ${ }^{29}$

\subsection{Susceptibility testing}

The Microbial Viability Assay Kit-WST, purchased from Dojindo Laboratories (Kumamoto, Japan), offers a method of microbial metabolism detection by colorimetry. According to the manufacturer's technical manual, WST-8, employed as a colorimetric indicator, is directly proportional to the number of living microorganisms.

Since the species and the metabolic activity have effects on the sensitivity (O.D. value), previous work has been done to optimize the number of cells and colouring reaction time for each test. After cultivation overnight, a bacterial suspension of $10^{7} \mathrm{CFU} \mathrm{mL}^{-1}$ using McFarland standards was prepared, further diluted with sterile saline to provide various densities, and then inoculated into a 96-well plate. After incubation for $6 \mathrm{~h}$ at $35^{\circ} \mathrm{C}, 10 \mu \mathrm{L}$ of the colouring reagent was added to each well, followed by another $2-3 \mathrm{~h}$ incubation. The O.D. value was measured at $450 \mathrm{~nm}$ with a microplate reader (Bio-Rad Laboratories, USA), and then the cell density corresponding to the O.D. value within a range of 2-4 was selected.

Bacteria were incubated at $37^{\circ} \mathrm{C}$ in broth at $150 \mathrm{rpm}$ overnight and then diluted to the proper density according to McFarland standards. After $90 \mu \mathrm{L} \mathrm{MH}$ broth was added to each well of columns 1 to 10 of the 96-well microplate, $\mathrm{Ga}\left(\mathrm{NO}_{3}\right)_{3}$ solution that had been prepared was added to the first well, followed by a serial two-fold dilution from columns 1 to 10 . After that, another $90 \mu \mathrm{L}$ MH broth was added to each well of columns 1 to 10, making the final volume $180 \mu \mathrm{L}$ and dilutions of 1024 to $2 \mu \mathrm{g} \mathrm{mL}{ }^{-1}$. Columns 11 and 12 were the positive and negative controls, respectively. A microbial suspension $(10 \mu \mathrm{L})$ was inoculated into each well of columns 1 to 11 , and the microplate was incubated for $6 \mathrm{~h}$ at $35{ }^{\circ} \mathrm{C}$. Then, $10 \mu \mathrm{L}$ colouring reagent (comprising nine parts WST solution and one part electron mediator reagent for Gramnegative bacteria, or nine parts WST solution and one part eight-fold diluted electron mediator reagent for Gram-positive bacteria) was added to each well of the microplate, with another incubation for $2-3 \mathrm{~h}$ at $35^{\circ} \mathrm{C}$. Finally, the microplate was read at $450 \mathrm{~nm}$ with a microplate reader (Bio-Rad Laboratories,
USA), and the negative control was read as the blank value. The MIC value was defined as the lowest concentration of gallium nitrate solution where the absorbance change was no more than 0.05 compared to the blank value..$^{30-32}$ The results are reported as the mean of the experiment that was conducted in triplicate.

\subsection{Transmission electron microscope (TEM)}

Representatives of Gram-negative and Gram-positive strains, $E$. coli and $S$. aureus, were cultivated in TSB broth $(99 \mathrm{~mL})$ at $150 \mathrm{rpm}$ at $37^{\circ} \mathrm{C}$ for $16 \mathrm{~h}$. Then, $1 \mathrm{~mL}$ of $\mathrm{Ga}\left(\mathrm{NO}_{3}\right)_{3}$ solution was added to the media, making the final concentration $32 \mu \mathrm{g} \mathrm{mL}^{-1}$ for both strains of bacteria. Cultivation was continued for 4 to $10 \mathrm{~h}$, and a culture with no $\mathrm{Ga}\left(\mathrm{NO}_{3}\right)_{3}$ served as a blank control. Five millilitres of culture media was collected and centrifuged, washed with PBS, and then fixed with $2.5 \%$ glutaraldehyde. After graded alcohol dehydration and Epon embedding, the sample was cut with an ultramicrotome and then stained with uranyl acetate and lead citrate. Then, the ultrathin section sample was ready for TEM observation. ${ }^{33}$

\section{Results}

\subsection{Optimal cell density for inoculation of different bacteria in WST-8 tests}

The sensitivity of WST-8 is related to the species of bacteria or the metabolic activity, so experiments have been done to optimize the number of cells for each species. The results are shown in Table 1.

\subsection{Determination of the $\mathrm{MIC}$ of $\mathrm{Ga}\left(\mathrm{NO}_{3}\right)_{3}$ against bacteria strains}

A few insoluble flocs existed in higher concentrations of medium-diluted $\mathrm{Ga}\left(\mathrm{NO}_{3}\right)_{3}$ solution, so $10 \mu \mathrm{L}$ of $0.2 \%$ EDTA solution was added to each well before measurement to eliminate the interference with absorbance and the microbial viability assay. The O.D. value obtained was in accordance with the ordinate, the abscissa concentration of the $\mathrm{Ga}\left(\mathrm{NO}_{3}\right)_{3}$ solution for a susceptibility curve for analysis of the results (Fig. 1).

According to Fig. 1(a), which shows strains of Gram-negative bacteria, the susceptibility curve was stable at the beginning
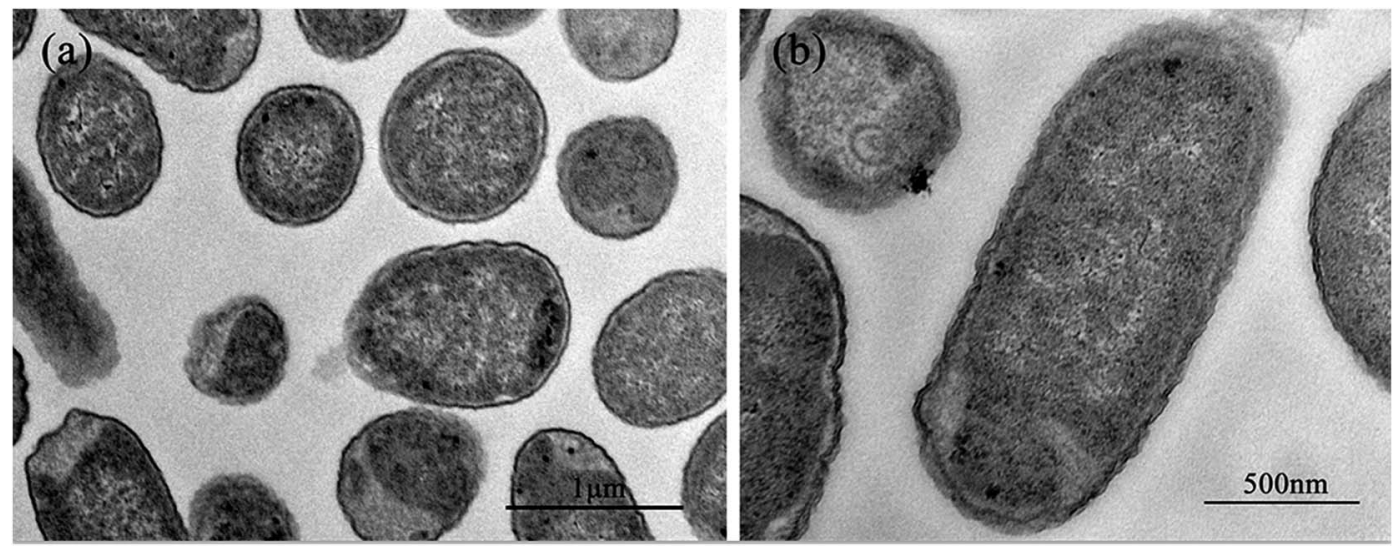

Fig. 2 Microstructure of normal E. coli cells. 
and began to decline at $16-64 \mu \mathrm{g} \mathrm{mL}{ }^{-1}$ with the rising $\mathrm{Ga}\left(\mathrm{NO}_{3}\right)_{3}$ concentration, which prompted the inhibition of bacterial growth. As the concentration constantly rose, the curve reached its lowest point close to the blank value at $256-512 \mu \mathrm{g} \mathrm{mL} \mathrm{m}^{-1}$, which revealed the fact that bacterial growth was completely inhibited. Based on the definition of the MIC in WST-8 tests, ${ }^{30-32}$ the concentration of $\mathrm{Ga}\left(\mathrm{NO}_{3}\right)_{3}$ at this point was read as the MIC against the experimental strain. Identical phenomena were found in Fig. 1(b), which shows strains of Gram-positive bacteria.

The MIC of $\mathrm{Ga}\left(\mathrm{NO}_{3}\right)_{3}$ was $256 \mu \mathrm{g} \mathrm{mL} \mathrm{m}^{-1}$ against $E$. coli and $E$. faecalis and $512 \mu \mathrm{g} \mathrm{mL}^{-1}$ against $P$. aeruginosa, $K$. pneumonia, $E$. cloacae, A. baumannii, S. aureus, S. epidermidis and S. maltophilia, as shown in Table 2.

\subsection{Microscopic appearance of $E$. coli after $\mathrm{Ga}^{3+}$ treatment}

Fig. 2 shows the normal microstructure of $E$. coli cells. Electron density uniformity was found in the cells with smooth borders, while DNA molecules, which appear as electron-light areas in TEM, were distributed randomly in the cells.

Micromorphological changes were found in $E$. coli cells after $\mathrm{Ga}^{3+}$ treatment (Fig. 3), and Fig. 3(a) gives an overview of these changes. The cell membrane was found to be rough, and shrinkage and detachment of the cell membrane and wall were
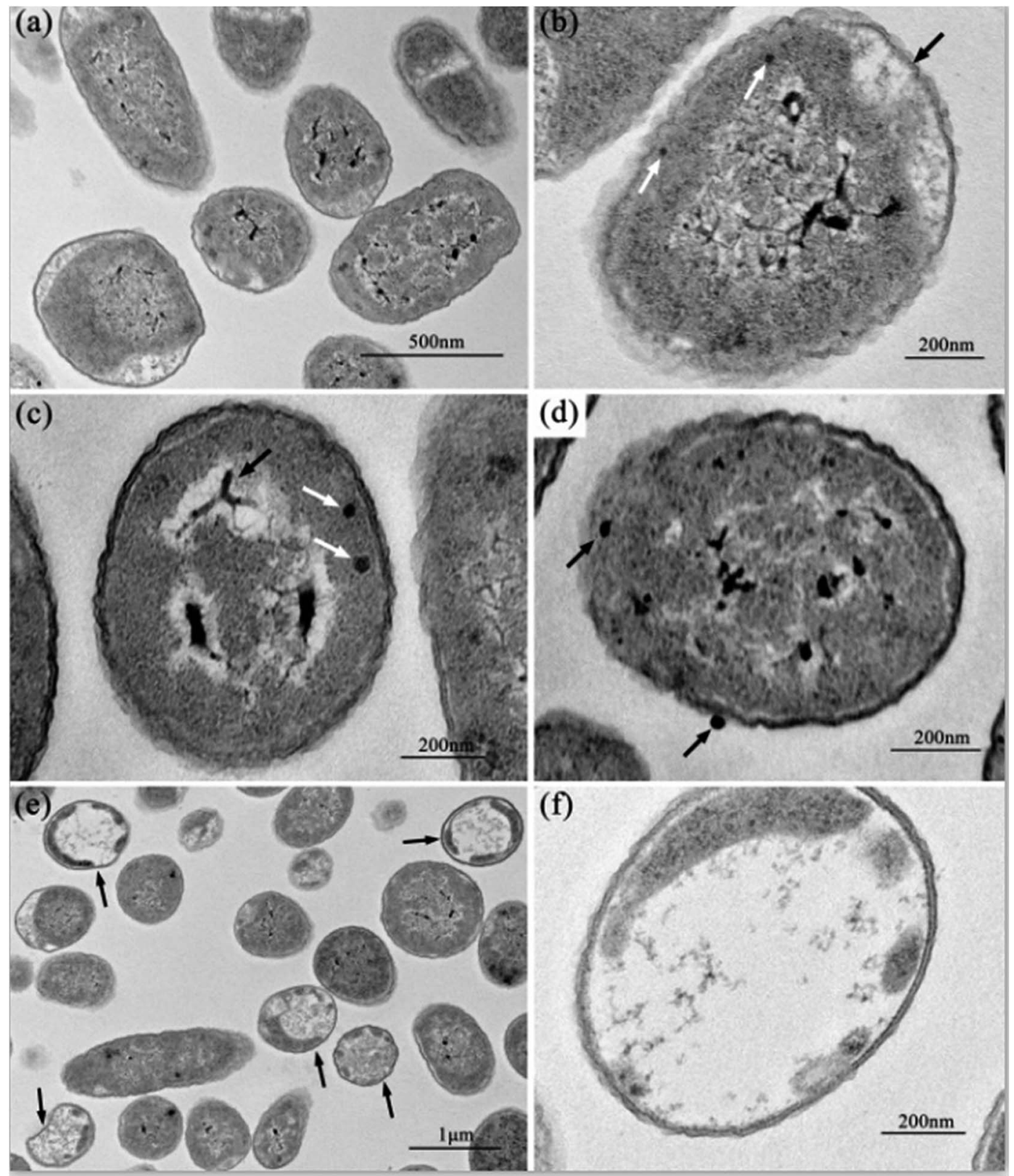

Fig. 3 Microstructure of $\mathrm{Ga}^{3+}$-treated E. coli cells. (a) An overview. (b) A large gap between the cell membrane and cell wall (black arrow) and intracellular high-density electronic granules (white arrow). (c) Strip-type electron-dense substances inside the electron-light region (black arrow), and intracellular high electron density granules (white arrow). (d) High electron density granules adhere to the cell wall. (e) and (f) Cells composed of a large electron-light region with substances sporadically distributed. 

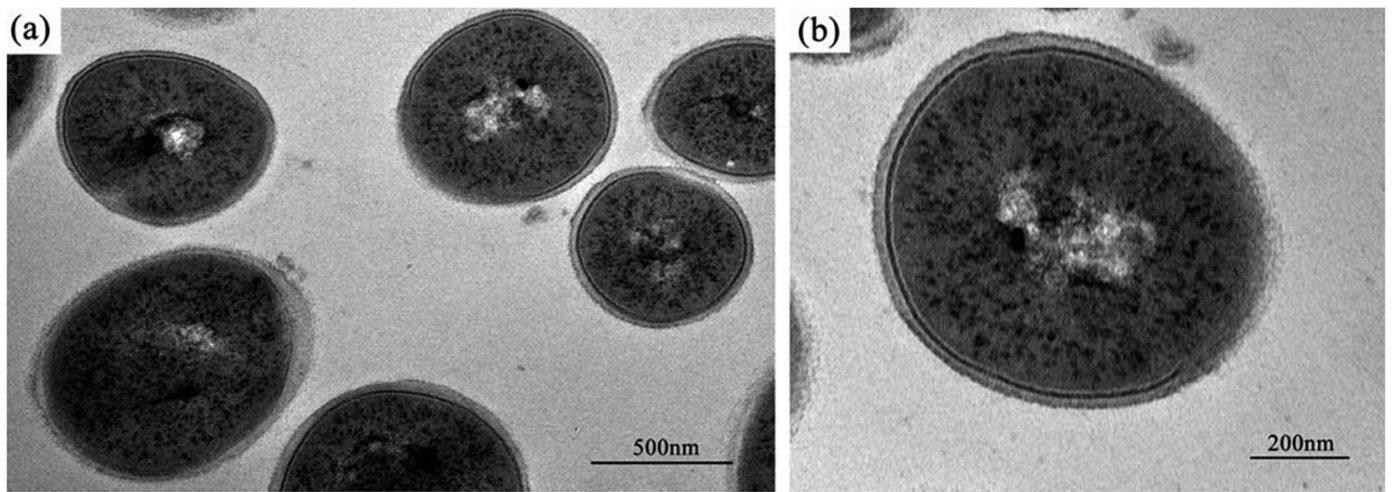

Fig. 4 Microstructure of normal S. aureus cells.
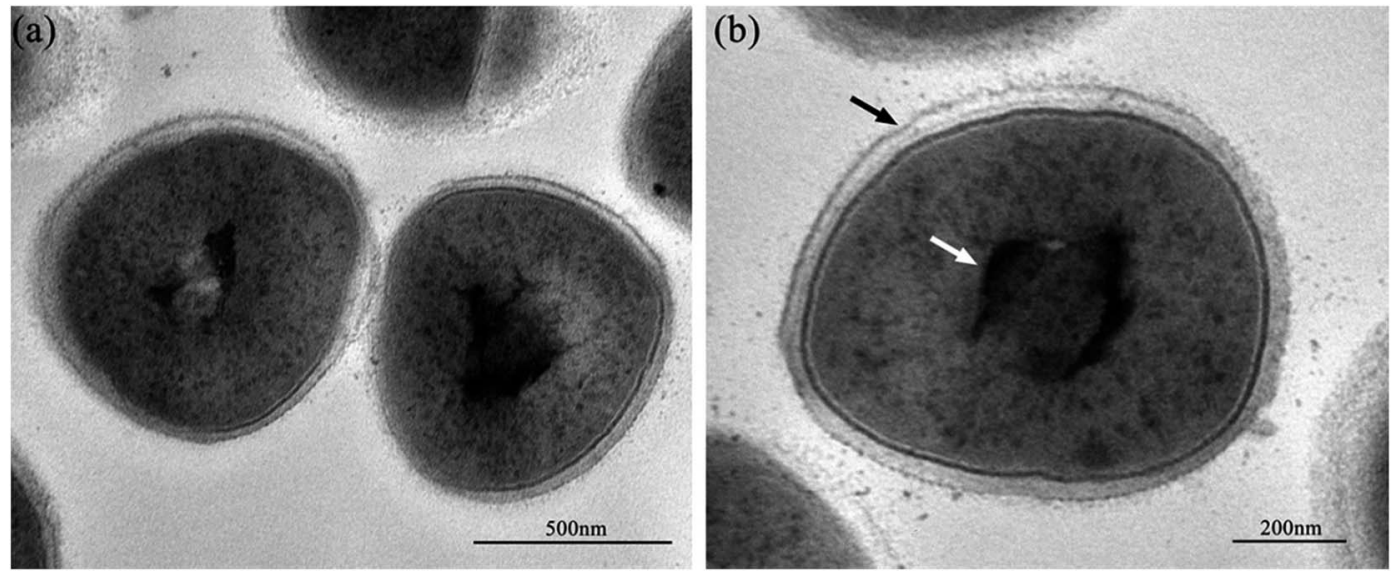

Fig. 5 Microstructure of $\mathrm{Ga}^{3+}$-treated S. aureus cells. (a) Intracellular electron-dense substances. (b) Cell membrane and wall was parted (black arrow), and intracellular condensed substances were present (white arrow).

also found in Fig. 3(b) (black arrow), while some part of the cell wall appeared indistinct in the TEM image, which may indicate damage of cell wall (Fig. 3(b) and (d)). Electron-light areas gathered in the centre of the treated cells, and some strip-type electron-dense substances were obvious in the electron-light region in Fig. 3(c) (black arrow). There were some high electron density granules adhering to the cell wall (Fig. 3(d)) or in the cytoplasm (Fig. 3(b) and (c), white arrow), which may be an indication of $\mathrm{Ga}^{3+}$ combining with some kind of molecule on the cell wall and/or invading into the cytoplasm.

Meanwhile, a particular appearance was found in some TEM images (Fig. 3(e) and (f)). Some cells, which appeared as lower electron densities in the picture, were composed of a large electron-light region with substances sporadically distributed, and some had indistinct images of cell walls. However, internal structures or substances were difficult to find in these cells. These cells were similar to capsules containing broken segments, which may be the final phase of the treated cells.

\subsection{Microscopic appearance of $S$. aureus after $\mathrm{Ga}^{3+}$ treatment}

The normal microstructure of $S$. aureus cells is shown in Fig. 4. It was found that $S$. aureus cells have a comparatively thicker cell wall and an apparent nucleoid containing DNA molecules, compared with E. coli cells.

Except for the smooth borders that were maintained after $\mathrm{Ga}^{3+}$ treatment in $S$. aureus cells, similar micromorphological changes occurred compared with E. coli cells (Fig. 5), such as the detachment of cell membrane and wall (Fig. 5(b), black arrow) and the appearance of condensed substances (Fig. 5(b), white arrow). In addition to these similarities, a few differences were also noted. On microscopic observation, the size of the electronlight region in $S$. aureus cell was smaller, and the density was much higher. In addition, the cell structure remained integral, and no broken segments had been found. This observation may suggest that $S$. aureus has a much stronger anti-gallium defence system.

\section{Discussion}

Wound infection, which may cause delays in re-epithelialization and poor wound healing, is one of the most common and intractable complications in burn patients. Even worse is that the pathogens in the infected wounds of patients with severe burns may cause bacteraemia, sepsis, multiple organ dysfunction syndrome (MODS), or even death. ${ }^{34}$ According to recent 
microbiological monitoring data, ${ }^{35,36}$ the detection rate of Gram-negative bacteria is much higher in burn wound infections, including $P$. aeruginosa, E. coli, A. baumannii, $K$. pneumonia, E. cloacae and S. maltophilia, followed by Grampositive bacteria, including $S$. aureus, $S$. epidermidis and E. faecalis. To face the challenge of increasing drug resistance, novel antimicrobial agents are greatly needed, and the use of gallium may represent a brand new treatment against bacterial infection.

Pathogens are exposed to iron limitation during infection, and must compete for $\mathrm{Fe}^{3+}$ retained by chelating proteins, ${ }^{37}$ so the competition for Fe becomes critical in the struggle between pathogen and host. Since $\mathrm{Ga}^{3+}$ and $\mathrm{Fe}^{3+}$ show very similar nuclear radii, the chemical behaviour of $\mathrm{Ga}^{3+}$ closely resembles that of $\mathrm{Fe}^{3+} \cdot{ }^{18}$ It is well known that $\mathrm{Fe}^{3+}$ is vitally important in many biologic systems and in the pathogen infection process. Therefore, the similarities in nuclear radius and coordination chemistry between $\mathrm{Ga}^{3+}$ and $\mathrm{Fe}^{3+}$ is what we can exploit to disturb iron metabolism to achieve the goal of antibacterial function. Our experiments observed the antibacterial activity of gallium nitrate $\left(\mathrm{Ga}\left(\mathrm{NO}_{3}\right)_{3}\right)$ solution against bacteria common in burn wound infections, and the MIC determined in our study was $512 \mu \mathrm{g} \mathrm{mL}{ }^{-1}$ for most strains of bacteria, with the exception of a MIC of $256 \mu \mathrm{g} \mathrm{mL} \mathrm{m}^{-1}$ against $E$. coli and E. faecalis. The results showed that gallium nitrate was a broad-spectrum antimicrobial agent against Gram-positive and Gram-negative bacteria. Furthermore, the MIC value exhibited that gallium nitrate had almost the same effect against both types of bacteria, which was strongly related to its antibacterial mechanism. If $\mathrm{Ga}^{3+}$ can affect most types of bacteria in burn wound infections, it may be an outstanding choice when we are faced with an infected wound.

In addition, biomaterial implants and devices have become one of the most important therapeutic methods currently when we try to repair a wound including burns. However, the deficiency in this approach or even life-threatening problem we must pay attention to is biomaterial-associated infection. Microbial contamination and infection can adversely affect all types of biomaterial implants and devices. ${ }^{2,3}$ Several methods have been explored and clinically studied in recent years to prevent implant infections in these contexts. For instance, antimicrobial agent coating strategies were extensively investigated. Kasetty ${ }^{38}$ coated a dermal substitute with host defence peptides, and its antibacterial effects were evaluated. Chen ${ }^{39}$ reported the in vivo antibacterial activity of a titanium substrate coated with melamine, a novel antimicrobial peptide that is being broadly studied. ${ }^{\mathbf{4 0}}$ Biocatalytic polymer-based antimicrobial coatings were also introduced and evaluated by Dave. ${ }^{41}$ Moreover, several ions, including silver, ${ }^{42,43}$ zinc $^{44}$ and copper, ${ }^{45}$ were exploited for the antibacterial modification of medical devices. In addition, other antibacterial strategies such as the use of non-adhesive ${ }^{46}$ or photocatalytic materials ${ }^{\mathbf{4 7}}$ were also discussed.

Meanwhile, many studies about medical devices with $\mathrm{Ga}^{3+}$ have been performed. Herron ${ }^{48}$ modified the surface of a biosynthetic dressing using $\mathrm{Ga}^{3+}$-loaded polyelectrolyte multilayers (PEMs), and confirmed its efficacy in controlling biofilm formation by $P$. aeruginosa. Mouriño ${ }^{14}$ coated 4555
Bioglass ${ }^{\circledR}$-based scaffolds with gallium-releasing 3D alginate, which empowered the composite scaffold ability of an antibacterial effect and improved mechanical properties. $\mathrm{Zhu}^{49}$ has reported that PVC plates coated with gallium nitrate could reduce bacterial cell aggregation on the PVC surface and inhibit biofilm formation associated with $P$. aeruginosa and $S$. pyogenes. As our study has determined the minimum inhibitory concentration of gallium nitrate against most pathogens in wound infections, it is worth performing further studies about how to modify medical devices or biomaterials with $\mathrm{Ga}^{3+}$, for example the method of sustained-release gelatine microspheres or microfilms, to prevent infection in burn wound.

The TEM scanning images showed us that similar phenomena occurred in $\mathrm{Ga}^{3+}$-treated $E$. coli and $S$. aureus cells, typical Gram-negative and Gram-positive bacterium. Those phenomena were the detachment of the cell membrane and cell wall and the appearance of an electron-light region containing condensed substances. These results suggested that the gallium ions inhibited both Gram-negative and Gram-positive bacteria, which was consistent with our MIC results.

The data show that Ga exerts its deleterious effects in two ways. First, gallium inactivates proteins by displacing Fe from its cognitive protein, and second, gallium causes the release of free $\mathrm{Fe}$ into the microenvironment, producing oxidative radicals that can induce cell death. ${ }^{50}$ According to the reported article, ${ }^{33}$ which used a similar TEM method, we can suppose the condensed substances to be DNA molecules. DNA replication is influenced when DNA molecules are in a condensed form. ${ }^{33}$ Therefore, it may be visual evidence of the dysfunction or damage of DNA molecules caused by gallium ion's interference. According to the reports, heavy metals can react with proteins and inactivate them. ${ }^{10}$ Since gallium $\left(\mathrm{Ga}^{3+}\right)$, a transition metal element, can combine with proteins, especially some significant enzymes, by replacing iron ions, we propose the cell walladherent or intracellular electron-dense granules seen in Fig. 3(b)-(d) should be a combination of gallium ions and proteins. On the other hand, internal structures or substances were absent, and only few broken segments can be seen in the same treated E. coli cells in Fig. 3(e) and (f), which is interpreted as the disruption caused by the reaction of gallium ions with internal proteins. These segments may be more visual evidence of gallium ions' antibacterial functions.

Although less significant morphological changes occurred and the cell structure remained integral after $\mathrm{Ga}^{3+}$ treatment in $S$. aureus cells compared with $E$. coli cells, the MIC results showed us the same antibacterial consequence of $\mathrm{Ga}^{3+}$ against both Gram-negative and Gram-positive bacteria. Considering this, despite images showing unbroken structures after treatment of $S$. aureus cells, the dysfunction or damage of DNA molecules and internal proteins had already occurred.

The Microbial Viability Assay Kit-WST is a brand new detection method of microbial metabolism by colorimetry. WST-8 provided in the kit produces a water-soluble formazan dye, the amount of which is proportional to the number of living microorganisms, by a reduction reaction of intracellular dehydrogenase through an electronic mediator. The WST-8 colorimetric method has been applied to susceptibility testing 
of various kinds of bacteria, and its advantages compared to the broth microdilution methods have been confirmed. ${ }^{32}$ It should be noted that, the accuracy of the results could be affected by the inoculated cell density according to different species, previous work should been done to decide the optimal cell densities for each test. Besides this, as a simple, rapid and effective MIC detection method, it is worthy of promotion.

\section{Conclusion}

Our study shows that gallium nitrate, as an efficient, inorganic antimicrobial that can fight most bacteria encountered in burn wound infections and against which there is little resistance, could be a good choice for clinicians faced with an infected burn wound. Gallium nitrate may also be a potential tool for biomaterial or medical devices to prevent infection in burn wounds as well. However, further studies are needed on the biocidal effect of gallium nitrate on fungi, which is also common in infected burn wounds, especially in patients who have used antibiotics intensively. Meanwhile, methods of effectively modifying biomaterials or medical devices with gallium ions still need further exploration.

\section{Conflicts of interest}

There are no conflicts to declare.

\section{Acknowledgements}

This work was funded by the National Nature Science Foundation of China (81120108015), the National Basic Research Programme of China (973 Programme, 2012CB518100), the "Twelfth Five-Year" Scientific Programme of China (AWS11J008, AWS14C001, 201502028), and the Clinical Key Discipline Project of Shanghai and China, and it was supported by the key Programme of National Clinical Specialty Discipline Construction of China (2012[649]) and the key Clinical Specialty Discipline Construction Programme of Fujian, China.

\section{References}

1 D. H. Hu, Z. F. Zhang, Y. G. Zhang, W. F. Zhang, H. T. Wang, W. X. Cai, X. Z. Bai, H. Y. Zhu, J. H. Shi and C. W. Tang, Burns, 2012, 38, 702-712.

2 H. J. Busscher, H. C. van der Mei, G. Subbiahdoss, P. C. Jutte, J. J. van den Dungen, S. A. Zaat, M. J. Schultz and D. W. Grainger, Sci. Transl. Med., 2012, 4, 153rv110.

3 K. G. Nichols, Z. Moaveni, C. Mcewan, A. Alkadhi, W. Mcewan and A. Alkadhi, Aust. N. Z. J. Surg., 2010, 79, A7. 4 C. Teplitz, D. Davis, A. D. Mason and J. A. Moncrief, J. Surg. Res., 1964, 4, 200-216.

5 A. A. Elmanama, N. A. Laham and G. A. Tayh, Burns, 2013, 39, 1612-1618.

6 S. Shleev, J. Tkac, A. Christenson, T. Ruzgas, A. I. Yaropolov, J. W. Whittaker and L. Gorton, Biosens. Bioelectron., 2005, 20, 2517-2554.

7 S. Prabhu and E. K. Poulose, Int. Nano Lett., 2012, 2, 32.
8 L. Sintubin, W. D. Windt, J. Dick, J. Mast, D. V. D. Ha, W. Verstraete and N. Boon, Appl. Microbiol. Biotechnol., 2009, 84, 741-749.

9 H. Palza, Int. J. Mol. Sci., 2015, 16, 2099.

10 Y. S. Lee, T. Meade, T. B. Norris and A. Galvanauskas, Lett. Appl. Microbiol., 1997, 25, 279-283.

11 S. Ferraris and S. Spriano, Mater. Sci. Eng., C, 2016, 61, 965. 12 L. Biao, S. Tan, Y. Wang, X. Guo, Y. Fu, F. Xu, Y. Zu and Z. Liu, Mater. Sci. Eng., C, 2017, 76, 73-80.

13 P. A. Zapata, M. Larrea, L. Tamayo, F. M. Rabagliati, M. I. Azócar and M. Páez, Mater. Sci. Eng., C, 2016, 69, 1282-1289.

14 V. Mouriño, P. Newby and A. R. Boccaccini, Adv. Eng. Mater., 2010, 12, B283-B291.

15 V. B. Kumar, M. Natan, G. Jacobi, Z. E. Porat, E. Banin and A. Gedanken, Int. J. Nanomed., 2017, 12, 725-730.

16 L. R. Bernstein, Pharmacol. Rev., 1998, 50, 665-682.

17 D. Chen, M. Frezza, R. Shakya, Q. C. Cui, V. Milacic, C. N. Verani and Q. P. Dou, Cancer Res., 2007, 67, 9258-9265.

18 P. Collery, B. Keppler, C. Madoulet and B. Desoize, Crit. Rev. Oncol. Hematol., 2002, 42, 283-296.

19 J. C. Dabrowiak, Metals in Medicine, 2009.

20 J. A. Lessa, G. L. Parrilha and H. Beraldo, Inorg. Chim. Acta, 2012, 393, 53-63.

21 T. Salifoglou, M. Drugs and M. Diagnostic Agents: The Use of Metals in Medicine, 2005.

22 J. R. Harrington, R. J. Martens, N. D. Cohen and L. R. Bernstein, J. Vet. Pharmacol. Ther., 2006, 29, 121-127.

23 Y. Kaneko, M. Thoendel, O. Olakanmi, B. E. Britigan and P. K. Singh, J. Clin. Invest., 2007, 117, 877.

24 C. E. Arnold, A. Bordin, S. D. Lawhon, M. C. Libal, L. R. Bernstein and N. D. Cohen, Vet. Microbiol., 2012, 155, 389-394.

25 L. C. Antunes, F. Imperi, F. Minandri and P. Visca, Antimicrob. Agents Chemother., 2012, 56, 5961-5970.

26 G. E. Xin, W. Hui and X. Dong, Chin. J. Infect. Chemother., 2013, 13, 136-139.

27 C. R. Chitambar and J. Narasimhan, Pathobiology, 1991, 59, 3-10.

28 M. C. Ammons, Recent Pat. Anti-Infect. Drug Discovery, 2010, $5,10$.

29 D. G. Filatova, I. F. Seregina, L. S. Foteeva, V. V. Pukhov, A. R. Timerbaev and M. A. Bolshov, Anal. Bioanal. Chem., 2011, 400, 709-714.

30 T. Tsukatani, H. Suenaga, T. Higuchi, T. Akao, M. Ishiyama, K. Ezoe and K. Matsumoto, J. Microbiol. Methods, 2008, 75, 109-116.

31 T. Tsukatani, T. Higuchi, H. Suenaga, T. Akao, M. Ishiyama, T. Ezoe and K. Matsumoto, Anal. Biochem., 2009, 393, 117125.

32 T. Tsukatania, H. Suenagaa, M. Shigab, K. Noguchib and M. Ishiyamab, J. Microbiol. Methods, 2012, 90, 160-166.

33 Q. L. Feng, J. Wu, G. Q. Chen, F. Z. Cui, T. N. Kim and J. O. Kim, J. Biomed. Mater. Res., 2000, 52, 662-668.

34 R. S. Lindsay, D. L. Church, B. W. Winston, S. Elsayed and O. Reid, Clin. Microbiol. Rev., 2006, 19, 403-434. 
35 R. Cooper, T. Bjarnsholt and M. Alhede, J. Wound Care, 2014, 23, 570-582.

36 C. Chen, Y. F. Fan, W. U. Wei-Wei, X. U. Xiao-Min and D. Yang, Chin. J. Nosocomiol., 2014, 24, 841-843.

37 E. D. Weinberg, Biochim. Biophys. Acta, Gen. Subj., 2009, 1790, 600-605.

38 G. Kasetty, M. Kalle, M. Mörgelin, J. C. Brune and A. Schmidtchen, Biomaterials, 2015, 53, 415.

39 R. Chen, M. D. Willcox, K. K. Ho, D. Smyth and N. Kumar, Biomaterials, 2016, 85, 142.

40 R. Rasul, N. Cole, D. Balasubramanian, R. Chen, N. Kumar and M. D. Willcox, Int. J. Antimicrob. Agents, 2010, 35, 566572.

41 R. N. Dave, H. M. Joshi and V. P. Venugopalan, Antimicrob. Agents Chemother., 2011, 55, 845-853.

42 T. S. Sileika, H. D. Kim, P. Maniak and P. B. Messersmith, ACS Appl. Mater. Interfaces, 2011, 3, 4602-4610.

43 W. Yao, X. Ding, C. Yuan, M. Guo, Z. Yan, X. Guo and H. Gu, Biomaterials, 2016, 101, 207.
44 K. Zheng, M. Lu, B. Rutkowski, X. Dai, Y. Yang, N. Taccardi, U. Stachewicz, A. Czyrskafilemonowicz, N. Hüser and A. R. Boccaccini, J. Mater. Chem. B, 2016, 4, 7936-7949.

45 J. Inkinen, R. Mäkinen, M. M. Keinänen-Toivola, K. Nordström and M. Ahonen, Lett. Appl. Microbiol., 2016, 64, 19.

46 N. P. Desai, S. F. Hossainy and J. A. Hubbell, Biomaterials, 1992, 13, 417-420.

47 H. M. Yadav, J. S. Kim and S. H. Pawar, Korean J. Chem. Eng., 2016, 33, 1989-1998.

48 M. Herron, M. J. Schurr, C. J. Murphy, J. F. Mcanulty, C. J. Czuprynski and N. L. Abbott, Adv. Healthcare Mater., 2015, 4, 2849-2859.

49 Y. Zhu, F. Jin, S. Yang, J. Li, D. Hu and L. Liao, Exp. Ther. Med., 2013, 5, 1001-1004.

50 C. Auger, J. Lemire, V. Appanna and V. D. Appanna, Gallium in Bacteria, Metabolic and Medical Implications, Springer, New York, 2013. 